Article

\title{
Effect of Corporate Governance Structure on the Financial Performance of Johannesburg Stock Exchange (JSE)-Listed Mining Firms
}

\author{
Isaih Dzingai and Michael Bamidele Fakoya *
}

Africa Centre for Sustainability Accounting and Management (ACSAM), School of Accountancy, University of Limpopo, Polokwane 0727, South Africa; isaih.dzingai@ul.ac.za

* Correspondence: michael.fakoya@ul.ac.za; Tel.: +27-152-683-312

Academic Editor: Yongrok Choi

Received: 6 May 2017; Accepted: 17 May 2017; Published: 8 June 2017

\begin{abstract}
There have been many corporate collapses and financial crises in recent years linked to a lack of effective corporate governance. The South African King IV Code of Corporate Governance recommends that corporate governing bodies should be comprised of an appropriate balance of knowledge, diversity, and independence for discharging their duties objectively and more efficiently. This study examines the effect of corporate governance structures on firm financial performance. The secondary data of selected Johannesburg Stock Exchange (JSE), Socially Responsible Investment (SRI) Index-listed mining firms' sustainability reports, and integrated annual financial statements are used. Using panel data analysis of the random effects model, we determined the relationship between board independence and board size and the return on equity (ROE) for the period 2010-2015. Results indicate a weak negative correlation between ROE and board size, and a weak, but positive, correlation between ROE and board independence. Additionally, there is a positive, but weak, correlation between ROE and sales growth, but a negative and weak relationship between ROE and firm size. The study suggests that effective corporate governance through a small effective board and monitoring by an independent board result in increased firm financial performance. We recommend that South African companies see compliance with the recommendations of the King IV Code on Corporate Governance not as a liability, but an ethical investment that may likely yield financial benefit in the long-term. Although complying with corporate governance principles does not necessarily translate into a significant economic benefit, firms should, however, continue to adopt corporate governance for ethical reasons to meet stakeholder's social and environmental needs for sustainable development.
\end{abstract}

Keywords: corporate governance; firm financial performance; return on assets; return on equity; Johannesburg Stock Exchange

\section{Introduction}

Modern corporate governance principles support an approach that considers and balances the legitimate and reasonable needs, interests, and expectations of its stakeholders in an inclusive, ethical, and sustainable manner as part of its decision-making. Corporate boards include not only those that pursue wealth creation as the sole objective, but also ethically responsible individuals who seek to improve social and environmental performances. Corporate governance has now become a mainstream concern of discussion in corporate boardrooms, educational meetings, and policy circles the world over [1]. Interest in corporate governance has increased since the turn of the century due to corporate fraud, managerial misconduct, and negligence and massive loss of shareholder wealth [2]. There are many reasons for such an explosive interest in this subject, but the main reason is corporate 
scandal [3]. Such explosive interest has resulted in heightened interest in the issue among researchers and policy-makers due to a series of unexpected corporate failures that has reignited and increased concerns regarding the effectiveness of board oversight [4].

Worldwide financial crises have prompted much government regulation, for example, the Sarbanes-Oxley Act, and have led to the persistent need for enhanced governance [5]. Since the formation of the King Committee in 1992 in South Africa with the objective of making recommendations on effective implementation of corporate governance, there have been developments in the reviewing of corporate governance standards. Due to a series of financial crises and corporate collapses in the past decade, people have lost confidence in the business sector [1]. Corporate collapses, like Enron and WorldCom, have led to the realisation of the effect and importance of a strong corporate governance system on financial performance of companies [6-9]. The 2009 global economic recession called for an increasing need to promote good corporate governance across the globe [10]. However, recent corporate scandals and business failures have spurred a lively debate on whether firms are adequately governed [11]. However, studies on corporate governance have focused more on developed countries, and little has been done in developing countries $[7,8]$.

In this study, we examine the influence of corporate governance structures on firm financial performance in South Africa among selected mining companies listed on the Johannesburg Stock Exchange (JSE). We chose the South African JSE because the King IV Code on Corporate Governance has become a major listing requirement for firms. The major impetus for investigating corporate governance of emerging economies is due to the significant growth in the number of companies from emerging economies listing on international stock exchanges to attract more foreign direct investments [8]. With the evidence of corporate scandals in South Africa, like Macmed, Leisurenet, and Regal Treasury Bank, in 1999, 2002, and 2001, respectively, there is, therefore, a need to investigate the impact that corporate governance has on firm financial performance. Since the mining industry contributes significantly to the gross domestic product of South Africa, and as a major force for advancing its economy, it is appropriate to analyse the effect of corporate governance on firm financial performance in this important sector. The study is structured as follows: the methods section follows the review of the literature, then results, discussion and, lastly, the conclusion.

\section{Theoretical Framework: Agency Theory}

Agency theory has become the cornerstone of corporate governance. It is the dominant theory to explain corporate governance, as per Akbar et al. [12]. Agency theory explains the conflicts of interests between the shareholders and managers, as explained by Ehikioya [8]. Due to conflicts of interest between agents (managers) and principals (owners), agency costs may arise. Misalignment of interests between managers and companies result in agency costs, and because of managers' preference for on-the-job perks, or by making self-entrenched decisions that may reduce shareholder's value, as per Ang et al. [13]. Due to this misalignment in objectives, agency costs are inevitably going to arise. There is a need to align managers' interests to the firm's interest through a code of governance. Sarens and Abdolmohammadi [14] explain that agency theory allows the agent to have more information than principals and that information asymmetry adversely affects the principals' ability to monitor if agents are properly serving their interests. Whatever the objective of a company, separating ownership and control may reduce agency problems, notably the asymmetry of information that arises between the agents and principals [15]. Hence, there should be an approach whereby the actions of firm's managers are monitored to avoid agency problems. Connelly et al. [16] suggest that because there is information asymmetry between agents and principals, there is the possibility that agents will act opportunistically in their interest rather than those of the principals. Principals do not have access to all of the information at the time agents make a decision; therefore, they are unable to determine whether the agents' actions are in the best interests of the firm. Information asymmetry is the heart of agency theory [15] resulting in managers pursuing their personal interests, which might be at the expense of the company. 


\section{Related Literature}

Corporate governance is essentially about effective leadership, which characterised by the ethical values of responsibility, accountability, fairness, and transparency [15]. It is the system or process of giving direction or control to companies [17]. A clear and functioning corporate governance system helps the firm to attract investment, raise funds, and strengthen the foundation for firm performance [6]. However, investors are more likely to be attracted to companies that disclose favourable corporate governance issues since they perceive well-governed firms to be less risky [7]. Hence, a company with a sound corporate governance structure will have improved performance [18]. Kyereboah-Coleman [19] found that outsized independent boards are likely to result in increased corporate value from a sample of African countries.

There has been a growing interest in the subject of corporate governance amongst various scholars. Although these studies have focused on the relationship between corporate governance and firm performance, the results have not been convergent [20]. Studies have concentrated on the link between corporate governance and firm financial performance with some showing a positive link, while others indicate a negative link or no association. For example, a study that examined if good corporate governance practices generate returns for firms on the Lima Stock Exchange (LSE) in Peru indicate that investors positively value the adoption of good corporate governance practices by companies listed on the LSE [21]. Their study concludes that an incentive existed for moneychangers in Peru, which added companies with good corporate governance to their equity portfolios. Another study established that the influence of good corporate governance on profitability varies across African countries, indicating that good corporate governance is more important for the stability of firms' profitability in countries with higher levels of good corporate governance ratings than those with lower ratings [22]. As such, good corporate governance can be an antidote to firm risk [23] and volatility of firm profits. Likewise, a significant and positive relationship between corporate governance practices and Tobin's $Q$ exists in a study on South African listed corporations [24]. Better governed South-African corporations tend to be associated with higher financial performance as the study found that good corporate governance practices reduce corporate failure, attract foreign direct investment and facilitate economic growth and development in South Africa [24].

A study that examined publicly-listed firms across Sub-Saharan African countries that have adopted good corporate governance practices, and its effect on firms' financial performance and market valuation, found companies complying with good corporate governance practices achieve higher financial performance [25]. Corporate governance is the process by which a company's business and affairs are managed to enhance business prosperity and shareholder wealth [20]. In their study on the link between corporate governance and firm performance, the results show a negative relationship between corporate governance and firm performance using Tobin's $Q$, price to book value, and price earnings [20]. However, Vintila and Gherghina [20] found no correlation between corporate governance and return on assets (ROA). A similar study in Sri Lanka examined the relationship between corporate governance and firm performance among 100 listed firms on the Colombo Stock Exchange for 2010-2012 financial years found a negative association between board size and firm performance [26]. Separating the role of the Chief Executive Officer (CEO) and chairman has a significant relationship with company performance, and having more non-executive directors on the board has no association with firm performance among listed firms in Sri Lanka.

Corporate governance impacts on cash holdings of companies with different investment policies comprising 1500 American Standard and Poor's firms show that CEO ownership and board independence affect cash holdings in listed firms differently [27]. However, there are indications that large boards result in the loss of productivity due to increased difficulties in coordinating the efforts of multiple individuals [27]. As such, Salvioni et al. [28] believe that sustainability can bring real convergence between outsider and insider corporate governance systems. Another study on the relationship between board committees and corporate performance that utilises publicly-available data 
of 346 firms of public firms in Hong Kong for the period 2001-2003 indicate that boards are perceived to be efficient and productive if they are comprised of independent non-executive directors [29].

The control and effectiveness of independent non-executive directors in Malaysian publicly-listed firms using a qualitative research design with interviews with board members of Malaysian-owned public limited firms suggest that non-executive directors are crucial to safeguarding interests of smaller investors, thereby contributing to the financial performance [30]. In establishing a relationship between corporate governance and firm performance in Pakistan oil and gas firms for the period 2004-2010, using panel data analysis and the ordinary least squares (OLS) method of estimation Dar et al. [31] found a significant and positive relationship between ROE and board size. Their result suggests that board size should be limited to a sizeable limit and that the CEO position rotates more often.

In emerging markets, in the link between corporate governance and firm valuation, it was established that there is usually a positive and significant relationship between corporate governance and valuation using regression analysis and that investors tend to invest in countries that practise good corporate governance [32]. An indication that money spent on improving firms' governance is worth the cost. Similarly, a study examining the relationship between firm-level corporate governance and firm value based on data from Governance Metrics International for 2300 companies from 22 developed countries for the period 2003-2007, concludes that corporate governance is an opportunity rather than an obligation and real cost factor [33].

However, some studies on the relationship between corporate governance and firm financial performance have shown neutral and mixed results. For instance, the correlation between corporate governance and firm financial performance was found by Li et al. to be mixed, prompting the conclusion that an executive's personality can affect both corporate governance structures and firm performance [34]. Although many studies show positive and mixed results on the relationship between corporate governance and firm financial performance, it concludes that there is no significant relationship between corporate governance and firm financial performance [35]. Of the 125 banking and finance firms listed on the Nepal Stock Exchange from which 59 firms were randomly selected using the Disclosure Index to collect data about mechanisms, commitment, transparency and attributes of corporate governance, results indicate a significant relationship between corporate governance and firm size, leverage, and foreign ownership [36]. Similarly, corporate governance is a social rather than a purely economic reality. Hence, the authors reiterate that due to the constant change and flow of corporate governance, driven by impetus and external factors, corporate governance cannot be limited to shareholder and stakeholder fixed mindsets, as this cannot fully capture the fluidity of corporate governance in reality [36].

Moreover, the relationship between board structure and firm performance using the Generalised Method of Moments (GMM) estimator in a panel of 6000 firms over a period of 1991-2003 suggests that there is no causal relationship between board structure and current firm performance [37]. Despite various studies showing positive and neutral results on the effects of corporate governance and firm economic performance, there are also studies which show a negative relationship. A study on corporate governance and firm value show that businesses that are less compliant with the provision of corporate governance earn positive abnormal returns compared to companies that are more compliant [18]. The study found evidence that rules associated with board independence and internal controls do not enhance the value of small businesses, rather, small companies suffer larger costs from implementing corporate governance practices than large corporations. Likewise, increases in the Governance Index level may result in economically-significant reductions in firm valuations with large negative abnormal returns during the period 1990-2003 [38].

In considering the mixed results and incongruities surrounding the relationship between corporate governance and firm performance from previous studies presented above, this study tests the effect of corporate governance on firm financial performance particularly using the return on equity (ROE) as a dependent variable. Although most studies on the link between corporate governance and firm financial performance have focused on developed economies' stock markets, such as America, 
Asia-Pacific, and Europe, few studies have focused on developing and emerging economies. A few exceptions, such as [24,39], examined the link between corporate governance and firm performance in emerging stock markets. The reason for the unavailability of literature on corporate governance in emerging nations is due to the lack of evidence from African stock markets [39]. However, South Africa has a mature business sector, deep equity culture, and strong regulatory and corporate governance frameworks compared to those of developed and other established markets [24].

\section{Materials and Methods}

The study used ten JSE SRI-listed mining companies to determine a relationship between corporate governance and firm financial performance. This study made use of mining firms listed on the JSE SRI because they are required, as part of their listing, to adhere to and apply the King IV Code of Corporate Governance in their business activities. The selected listed companies were consistent on the JSE SRI Index which only entered into force in 2009 with publicly-available data from 2010-2015. Data were analysed over six (6) years to enable the use of a balanced panel data analysis to determine whether the observed relationship between corporate governance structure and firm performance holds over time. The study employs corporate governance variables as the independent variables and company financial performance indicators as the dependent variables. This study extracted data from annual integrated and sustainability reports of selected companies. The annual integrated reports were from the INET BFA website [40]. Financial indicators employed in this study were from the INET BFA website.

Two corporate governance variables, namely, board size and board independence were used as the independent variables. Regarding the board size, the King IV Code of Corporate Governance recommends the governing body to be comprised of an appropriate mix of knowledge, skills, and business and industry experience needed to govern the organisation. The King Code of Corporate Governance also recommends that the governing body be comprised of an appropriate balance of knowledge, diversity, and independence for it to discharge its duties objectively and efficiently. All JSE-listed firms are required to comply and explain the application of the corporate governance recommendations. For financial performance indicators, ROE was a proxy for the dependent variable. Given the nature of the data for this study and to allow for time series and cross-sectional data observations, the study employed a balanced panel data analysis. In line with previous studies, such as [41] and [24], the study employs two-panel data techniques, which are the fixed-effects model and the random effects model, to control for possible unobserved firm-level heterogeneities. The Hausman test is used to identify if the individual effects are fixed or random, in cases where individual effects exist. In determining a relationship between corporate governance and firm financial performance, we formulated the hypothesis and regression equation below:

H1: Corporate governance structure influences return on equity (ROE) among selected JSE SRI listed mining firms

Following previous studies, such as [27,42], the following regression equation is used:

$$
\mathrm{ROE}_{\mathrm{it}}=\alpha_{\mathrm{i}}++\beta \text { BoardIndep }_{\mathrm{it} 1}+\beta \mathrm{BSIZE}_{\mathrm{it} 2}+\beta \mathrm{SIZE}_{\mathrm{it} 3}+\beta \text { SGrowth }_{\mathrm{it} 4}
$$

where $\mathrm{ROE}_{\mathrm{it}}=$ return on equity, BoardIndep $\mathrm{it}_{1}=$ proportion of non-executive directors, $\mathrm{BSIZE}_{\mathrm{it} 2}=$ board size, $\mathrm{SIZE}_{\mathrm{it} 3}=$ firm size, $\mathrm{SGrowth}_{\mathrm{it} 4}=$ sales growth, $\alpha_{\mathrm{i}}=$ intercept , and $\beta=$ gradient $/$ slope .

In testing the hypothesis above, corporate governance variables are the independent variables, while ROE was a proxy for financial performance, which is the dependent variable. Firm size and sales growth are control variables since different characteristics of a firm can affect both a company's financial performance and its corporate governance practices in various ways.

This study employed ROE as the financial performance indicator following previous studies, such as $[27,43]$. This study made use of ROE as a measure of financial performance since investors are 
more interested in ROE and its changes, which provide an indication of the firm's efficiency. Moreover, stakeholders, such as investors, are more interested in the appreciation of the value of the company's equity. The use of board size and board independence as corporate governance variables in this study follows the recommendations of the King IV Code of Corporate Governance that the board should be comprised more of independent non-executive directors. This study also follows previous studies, such as $[30,31]$. The use of board size as a corporate governance variable follows previous studies, such as $[44,45]$, which suggest larger boards with high levels of links to the external environment to improve the firm's access to various resources which, in turn, positively influence corporate performance. Previous studies, such as $[25,46]$, opine that large firms have more competitive power when compared to smaller businesses and can profit more. This study employs firm size as a control variable since it also affects the financial performance of a firm [47]. Following previous studies, such as [12,48], this study also uses sales growth as a control variable, which also affects firm financial performance.

\section{Results}

The section presents and discusses the study findings. Table 1 shows the data for the descriptive statistics.

Table 1. Summary of the descriptive statistics.

\begin{tabular}{cccccc}
\hline Variable & Obs & Mean & Std. Dev. & Min & Max \\
\hline Roe & 60 & 11.76127 & 27.84148 & -66.9384 & 107.636 \\
Board size & 60 & 11.38333 & 2.415288 & 6.00 & 17.00 \\
Board indep & 60 & 78.48033 & 9.231522 & 52.94 & 92.86 \\
Sales growth & 60 & 7.540982 & 18.70769 & -49.5868 & 65.3452 \\
Firm size & 60 & $21,010.3$ & $42,145.88$ & 27.875 & 282,333 \\
\hline
\end{tabular}

Source: Authors' result of descriptive statistics from Stata.

The descriptive statistics allow the researcher to describe the many pieces of data with a few indices. The panel data captured data for ten firms for the period 2010-2015 (which is six years) making 60 observations in total. Table 2 shows results of the independent $t$-test of the study variables.

Table 2. Two-sample $t$-test with equal variances ( $t$-test sales growth $=$ firm size, unpaired).

\begin{tabular}{ccccccc}
\hline Variable & Obs & Mean & Std. Err. & Std. Dev. & \multicolumn{2}{c}{ [95\% Conf. Interval] } \\
\hline Salesgrowth & 60 & 7.540982 & 2.415153 & 18.70769 & 2.708272 & 12.37369 \\
Firmsize & 60 & $21,010.3$ & 5441.009 & $42,145.88$ & $10,122.87$ & $31,897.74$ \\
Combined & 120 & $10,508.92$ & 2875.007 & $31,494.13$ & 4816.12 & $16,201.72$ \\
Diff & $-21,002.76$ & 5441.01 & $-31,777.44$ & $-10,228.08$ & &
\end{tabular}

Note: diff $=$ mean(salesgrowth $)-$ mean(firmsize); $\mathrm{t}=-3.8601 ;$ Ho: diff $=0 ;$ Ha: diff $<0$; Ha: diff! = 0; Ha: diff $>0$; degrees of freedom $=118 ; \operatorname{Pr}(\mathrm{T}<\mathrm{t})=0.0001 ; \operatorname{Pr}(|\mathrm{T}|>|\mathrm{t}|)=0.0002 ; \operatorname{Pr}(\mathrm{T}>\mathrm{t})=0.9999$; source: Authors' result of $t$-test from Stata.

Table 2 presents an independent $t$-test that was run on a sample of 120 combined obs of independent variables (sales growth and firm size) to determine if they influence ROE differently. Both IVs consisted of 60 randomly-assigned observations. The results showed that sales growth had statistically significantly lower $(7.54 \pm 2.42)$ influence on ROE compared to firm size $(21,010.3 \pm 5441.00)$. Hence, sales growth and firm size were not statistically significant with respect to influencing ROE.

Table 3 shows the correlations between the dependent variable (ROE) and independent variables (board size, board independence, sales growth, and firm size). 
Table 3. Correlations between individual variables.

\begin{tabular}{cccccc}
\hline & Roe & Board Size & Board Indep & Sales Growth & Firm Size \\
\hline Roe & 1 & & & & \\
Boardsize & -0.07 & 1 & 1 & & \\
Boardindep & 0.15 & 0.0742 & 0.0018 & 1 & \\
Salesgrowth & 0.27 & -0.0251 & -0.3193 & -0.0537 & 1 \\
Firmsize & -0.1 & 0.4324 & & \\
\hline \multicolumn{5}{r}{ Source: Authors' result of correlation between individual variables from Stata. }
\end{tabular}

Tables 3 and 4 above show a weak negative correlation between ROE and board size of -0.07 . The results imply that adding more directors on the board will decrease the financial performance of the firm, suggesting that a large board may not necessarily increase the value to the company. Previous studies by Azeez [26], Bliss [49], and Chen [27] support our result. Our results suggest that a small board is likely to lead to a higher performance because it avoids the problem of free riding which occurs among large boards. Two critical issues likely to be affected by a large board are the issues of responsibility and accountability. It may be difficult to have cohesiveness and easy communication amongst a large group. In their studies, Azeez) [26] found that a small board leads to higher performance due to close monitoring of the few directors on the board. Tables 3 and 4 also show a weak positive correlation between ROE and board independence of 0.15 . The supervisory role provided by non-executive directors helps to safeguard shareholders' wealth and ensures that there is no conflict of interest between agents and principals (Annuar and Rashid) [30]. Non-executive directors bring independence to the board, adding to the diversity of skills and expertise of the directors. Moreover, non-executive directors alleviate agency problems and reduce managerial self-interests due to the separation of ownership and control. The results of this study are consistent with studies, such as Chen, which advocate that firms should include more independent directors on their boards to ensure profitability and efficient operations. Independent non-executive directors should oversee directors' actions and protect the shareholders' investments. Table 4 presents result of the mixed-effects multi-level (ML) regression analysis.

Table 4. Mixed-effects multi-level regression.

\begin{tabular}{|c|c|c|c|c|c|c|}
\hline Roe & Coef. & Std. Err. & $\mathbf{z}$ & $p>\mathrm{z}$ & \multicolumn{2}{|c|}{ [95\% Conf. Interval] } \\
\hline Boardsize & -0.487473 & 1.618894 & -0.3 & 0.763 & -3.660447 & 2.685502 \\
\hline Boardindep & 0.491414 & 0.4030682 & 1.22 & 0.223 & -0.2985855 & 1.281413 \\
\hline Salesgrowth & 0.40181 & 0.1828395 & 2.2 & 0.028 & 0.0434508 & 0.7601686 \\
\hline Firmsize & 0.000017 & 0.0000978 & 0.17 & 0.862 & -0.0001746 & 0.0002086 \\
\hline _cons & -24.64363 & 32.92556 & -0.8 & 0.454 & -89.17654 & 39.88928 \\
\hline \multicolumn{3}{|c|}{ Random-Effects Parameters } & Estimate & Std. Err. & \multicolumn{2}{|c|}{ [95\% Conf. Interval] } \\
\hline \multicolumn{3}{|c|}{ sd(Residual) } & 26.23195 & 2.394639 & 21.93446 & 31.3714 \\
\hline
\end{tabular}

Note: Number of obs = 60; Wald chi2(4) = 6.46; Log likelihood $=-281.155$; Prob $>$ chi $^{2}=0.1672$. Roe: return on equity; Std. Err.: standard error; z: z-score; $p$ : $p$-value; source: Authors' result of ML-Effects from Stata.

The results suggest that a small board is likely to lead to a higher performance because it avoids the problem of free riding which occurs among large boards. Two critical issues affected by a large board are the issues of responsibility and accountability. Having cohesiveness and easy communication amongst a large group is difficult. In their studies, Chen [27] and Chen [45] found that a small board leads to higher performance due to close monitoring of the few directors on the board. Where there are close monitoring and excellent communication amongst the board members, there is more likely to be higher productivity. To reap greater rewards in business is a matter of taking risks. Lam and Lee [29] found that larger boards mean lower profitability because these boards of directors are more conservative with less risk taking. With a large board that is more conservative with less risk taking, an 
entity will not be able to be financially successful and competitive in the market. Our analysis agrees with studies, such as [32], which suggest that the size of the board must be restricted and monitored for it to be efficient and to add value to the firm. A small board will be able to exercise sound judgments and set a level of risk and tolerance for the company that will lead to an increase in firm success.

The results of this study suggest that effective monitoring by an independent and efficient board motivates managers to perform in the interests of the shareholders, thereby improving the ROE. However, the results are inconsistent with previous studies of Azeez [26] and Syriopoloulos and Tsatsaronis [50], who suggest that there is no relationship between board independence and firm performance. In his study, Azeez [26] found that increasing the number of non-executive directors does not contribute to adding value to the firm. Additionally, Li et al. [34] opine that outside independent directors do not contribute to corporate performance unless the board is gender-diversified.

To sum all of this up, the results support the hypothesis that corporate governance influences firm financial performance.

Furthermore, there is a positive, but weak, correlation between ROE and sales growth of 0.27 , but a negative and low relationship between ROE and company size of -0.10 . It is plausible that an efficient use of the business's assets (resources) will generate positive earnings that may be available to equity holders. A negative, but insignificant, correlation exists between board size and firm size and the dependent variable (ROE). There appears to be no multi-collinearity as this has been eliminated using Stata. Although board independence and sales growth have a positive correlation, they are insignificant with respect to influencing the dependent variable.

Given the above result, it is evident that board size and board independence are important factors that affect firm performance. Monitoring of the board size is necessary for it to be effective. Board independence is also crucial for the functioning and profitability of the company. Such monitoring by independent directors is in line with the King IV recommendation for firms to include most independent non-executive directors on the board for effective oversight and transparency.

The study used two models of panel data analysis, which are the fixed effects model and the random effects model.

In testing the relationship between corporate governance variables and ROE, we ran the fixed effects model and random effects models. Tables 5 and 6 below shows the panel data results using the fixed effects model for return on assets (ROE).

Table 5. Input for the fixed effect model for ROE.

\begin{tabular}{cc}
\hline Fixed-Effects (within) Regression & Number of Obs $=\mathbf{6 0}$ \\
\hline Group variable: firmcode & Number of groups $=10$ \\
$\mathrm{R}^{2}:$ & Obs per group \\
Within $=0.1927$ & $\min =6$ \\
Between $=0.0151$ & $\operatorname{avg}=6.0$ \\
Overall $=0.0249$ & $\max =6$ \\
& $\mathrm{~F}(4,46)=2.74$ \\
Corr $\left(\mathrm{u} \_\mathrm{i}, \mathrm{Xb}\right)=-0.8009$ & prob $>\mathrm{F}=0.0395$ \\
\hline
\end{tabular}

Note: number of Obs = 60: total number of observation (rows); Number of groups $=10$ : total number of groups (entities); If this number is $<0.05$ then your model is ok. $F(4.46)=2.74, p r o b>F=0.0395$ : this is a test $(F)$ to see whether all the coefficients in the model are different than zero; Corr $\left(u_{-} \mathrm{i}, \mathrm{Xb}\right)=-0.8009$ : the errors ui are correlated with the regressors in the fixed effects model. 
Table 6. Fixed effects model for ROE.

\begin{tabular}{ccccccc}
\hline ROE & Coef. & Std. Err. & $t$ & $p>|\mathbf{t}|$ & \multicolumn{2}{c}{ [95\% Conf. Interval] } \\
\hline Board size & -1.850736 & 2.379191 & -0.78 & 0.441 & -6.639798 & 2.938326 \\
Board indep. & 0.4987432 & 0.5422147 & 0.92 & 0.362 & -0.5926785 & 1.590165 \\
Sales growth & 0.3601961 & 0.1323431 & 2.72 & 0.009 & 0.0938032 & 0.626589 \\
Firm size & -0.0012114 & 0.0007551 & -1.60 & 0.115 & -0.0027314 & 0.0003085 \\
-cons & 11.29327 & 41.67712 & 0.27 & 0.788 & -72.59842 & 95.18496 \\
Sigma_u & & \multicolumn{5}{c}{38.60104} \\
Sigma_e & & \multicolumn{3}{c}{18.499271} \\
Rho & & 0.81322388 (fraction of variance due to u_i)
\end{tabular}

Note: sigma_u $=$ sd of residuals within groups ui; sigma_e $=$ sd of residuals (overall error term) ei; Rho $=81.3 \%$ of the variance is due to differences across panels; 'rho' is known as the intra-class correlation; $t=\mathrm{t}$-values test the hypothesis that each coefficient is different from 0 . To reject this, the $t$-value has to be higher than 1.96 (for a $95 \%$ confidence). If this is the case then you can say that the variable has a significant influence on your dependent variable (y). The higher the $t$-value the higher the relevance of the variable; $p>|t|=t w o$-tail $p$-values test the hypothesis that each coefficient is different from 0 . To reject this, the p-value has to be lower than 0.05 ( $95 \%$, you could choose also an alpha of 0.10 ), if this is the case then you can say that the variable has a significant influence on your dependent variable (y); Source: Authors' result of fixed effects model for ROE from Stata.

\subsection{Fixed Effect Model for ROE}

From Table 6 above the relevant statistics to take note of are the coefficient of the regressors and $p$-values. The significance level is set to $95 \%$ significant levels with $p$-values greater than 0.05 interpreted to be insignificant. The above results in Table 6 show that there is a negative, but insignificant, correlation between board size and ROE represented by a coefficient of -1.85 and $p$-value of 0.441 . The result shows that board size has a negative and insignificant influence on ROE.

The results also show that there is a positive, but insignificant, correlation between board independence and ROE indicated by a coefficient of 0.50 and $p$-value of 0.36 , an indication that board independence has a positive and insignificant influence on ROE.

The results also show a positive correlation between sales growth and ROE indicated by a coefficient of 0.36 and $p$-value of 0.009 . Moreover, the results also show that there is a negative correlation between firm size and ROA represented by a coefficient of -0.0012114 and $p$-value of 0.115 .

Tables 7 and 8 present the results for the random effects model for ROE.

Table 7. Random effects model for ROE.

\begin{tabular}{cc}
\hline Random Effects GLS Regression & Number of Obs $=\mathbf{6 0}$ \\
\hline Group variable: Firm Code & Number of groups $=10$ \\
$\mathrm{R}^{2}:$ & Obs per group: \\
Within $=0.1625$ & $\min =6$ \\
Between $=0.0216$ & $\operatorname{avg}=6.0$ \\
Overall $=0.638$ & $\max =6$ \\
& Wald $\operatorname{Chi}^{2}(4)=9.25$ \\
Corr $\left(\mathrm{u} \_\mathrm{i}, \mathrm{X}\right)=0$ (assumed) & prob $>\mathrm{Chi}^{2}=0.0551$ \\
\hline
\end{tabular}

Table 8. Random effects model for ROE.

\begin{tabular}{ccccccc}
\hline ROE & Coef. & Std. Err. & $\mathbf{Z}$ & $p>|\mathbf{z}|$ & \multicolumn{2}{c}{ [95\% Conf. Interval] } \\
\hline Board size & -1.118868 & 2.078363 & -0.54 & 0.590 & -5.192364 & 2.954628 \\
Board indep & 0.195052 & 0.4395305 & 0.44 & 0.657 & -0.666412 & 1.056516 \\
Sales growth & 0.3675898 & 0.1300185 & 2.83 & 0.005 & 0.1127583 & 0.6224213 \\
Firm size & -0.0002423 & 0.0003319 & -0.73 & 0.465 & -0.0008927 & 0.0004081 \\
_cons & 10.4826 & 38.63017 & 0.27 & 0.786 & -65.23114 & 86.19635 \\
Sigma_u & & \multicolumn{5}{c}{27.226071} \\
Sigma_e & \multicolumn{5}{c}{18.499271} \\
Rho & 0.68414516 (fraction of variance due to u_i) \\
\hline
\end{tabular}

Source: Authors' result of random effects model for ROE from Stata. 
From the above table, the vital statistics to take note of is the coefficient of the regressors and $p$-values. The significant levels have been set to $95 \%$ significant levels with $p$-values greater than 0.05 , interpreted to be insignificant. The results show that there is a negative, but insignificant, correlation between board size and ROE, demonstrated by a coefficient of -1.12 and $p$-value of 0.59 . An indication that, for any increase in the board size by one director, there is a decrease in ROE by $1.12 \%$.

Results indicate a positive, but insignificant, correlation between board independence and ROE demonstrated by a coefficient of 0.20 and $p$-value of 0.66 . The result shows that, for any independent non-executive director added to the board, there will be an increase of ROE by $0.195 \%$.

The results indicate that there is a positive, but insignificant, correlation between sales growth and ROE demonstrated by a coefficient of 0.37 and $p$-value of 0.005 and a negative, but insignificant, correlation between firm size and ROE demonstrated by the coefficient of -0.0002423 and $p$-value of 0.47 .

In deciding between fixed effects or random effects models for ROE, we ran the Hausman test, where the null hypothesis confirms that the preferred model is the random effects model, while the alternative is the fixed effects model. Table 9 below shows the Hausman test results for ROE.

Table 9. Hausman test for ROE.

\begin{tabular}{ccccc}
\hline & $(\mathbf{b})$ & $\mathbf{( B )}$ & $\mathbf{( b - B )}$ & Sqrt (diag (V_b-V_B)) \\
\hline & Fixed & Random & Difference & S.E. \\
\hline Board size & -1.850736 & -1.118868 & -0.731868 & 1.158015 \\
Board indep & 0.4987432 & 0.195052 & -0.3036912 & 0.3175055 \\
Sales growth & 0.3601961 & 0.3675898 & -0.0073937 & 0.0246962 \\
Firm size & -0.0012114 & -0.0002423 & -0.0009691 & 0.0006783 \\
\hline
\end{tabular}

Note: $\mathrm{b}=$ consistent under Ho and Ha; obtained from xtreg; B = inconsistent under Ha, efficient under Ho; obtained from xtreg; Source: Authors' result of Hausman test for ROE from Stata. Test: Ho difference in coefficient not systematic. Chi ${ }^{2}(3)=(b-B)^{\prime}\left[(\text { V_b-V_B })^{\wedge}(-1)\right](b-B)=2.38 ;$ Prob $>=0.6668$.

\subsection{Hausman Tests for ROE}

The results below are the results for the Hausman test for ROE.

The above results from the Hausman test run emphasise the use of the random effects model since prob $>\mathrm{Chi}^{2}=0.67$ is greater than 0.05 . Therefore, for this study, the results from the random-effects model are used to establish the correlation between the dependent variable (ROE) and the independent variables.

The following section discusses the findings.

\section{Discussion}

The descriptive statistics suggest that JSE SRI-listed mining firms are moving towards practising good corporate governance, as shown by the majority $(50 \%+)$ of independent non-executive directors on the board. Having a majority of independent board members is in line with King IV recommendations for firms to include a larger number of independent non-executive directors for independence on the board. These results also are consistent with Chen [27] who found that Sri Lankan-listed firms are also moving towards practising good corporate governance mechanisms by incorporating a higher proportion of non-executive directors on corporate boards. Sri Lanka is also an emerging economy, like South Africa, which seeks to promote sound governance among listed firms, improve investor confidence, and foster economic development. Sound governance is to ensure that corporate boards are seen to be acting independently in its conduct and operations.

The descriptive statistics also suggest that JSE-listed firms are incorporating a good number $(50 \%+)$ of non-executive directors on corporate boards as shown by the mean. Having independent majority members on corporate boards is also consistent with the King IV recommendations for the 
boards to have sufficient and qualified members to serve on corporate boards. A board with diversity provides collective skills, knowledge, and expertise, which are necessary for company financial success.

The results from the Hausman test suggest the use of the random effects model in testing both hypotheses for this study.

\subsection{Random Effects Model: Board Size and Firm Performance (ROE)}

The results from the random effects model suggest that there is a negative relationship between board size and firm performance when measured by ROE, as indicated by a coefficient of -1.118868 . The results imply that adding more directors to the board will decrease the financial performance of the firm, suggesting that a large board may not necessarily increase the value to the company. This is supported by previous studies by $[27,29,49,51]$. Boubaker et al. found that large boards result in a loss of productivity and losses are mainly due to increased difficulties in coordinating the efforts of multiple individuals, which also results in slower decision-making and more free riding [52]. The results of this study by Boubaker et al. also indicate that, for a firm to be profitable, a small, effective board which is easy to manage and, thus, enhancing quick decision-making, may just be enough [52].

It is the duty of the board to maximise shareholder wealth. Therefore, optimal board size is essential to the financial success of a firm. The King IV Code of Corporate Governance emphasises that good governance hinges on ethical culture, effective control, good performance, and legitimacy. Our results are inconsistent with previous studies, such as that of Bebchuk et al. [38], who suggest that there is a positive relationship between board size and firm performance. Their study suggests that the knowledge and expertise of a large board can be utilised for strategic decision-making, thereby enhancing business value. Large boards have been argued to increase information sharing which leads to more strategic ideas. However, our results suggest that the benefits caused by a large board outweigh the many problems caused by having too many directors on the board. Succinctly, our results support the hypothesis that corporate governance influences firm performance, as measured by ROE, implying that investors are willing to invest in companies which comply with sound corporate governance principles to increase the value of the enterprise. Our results suggest that investors are likely to be attracted to firms which are listed on the JSE since they comply with the King IV Code of Corporate Governance principles.

\subsection{Random Effects Model: Board Independence and Firm Performance}

However, results of the random-effects model suggest a positive relationship between board independence and firm performance, as measured by ROE, an implication that the more independent non-executive directors added to the board, the more profitable the firm becomes. Per King IV, the board of directors should consist mostly of independent non-executive directors to ensure transparency and monitoring by non-executive directors for efficiency in running the business of the firm, thereby reducing agency costs. The results are consistent with previous studies, such as Byrd et al. [53] and Lam and Lee [29], who also found that there is a positive relationship between board independence and firm performance. In support, Annuar and Abdul Rashid [30] found that boards are perceived as efficient and productive if they are comprised of more independent non-executive directors. A suggestion that a board which comprises mostly of independent directors increases the likelihood that decisions made will likely be in the best interests of the firm. Independence of the board and close monitoring by the non-executive directors may prevent management from agency problems, like abusing the use of the company's funds on paying out excessive benefits, such as generous salaries, pension entitlements, bonuses, and share options to executive directors.

The monitoring role provided by non-executive directors helps to safeguard shareholders' wealth and ensures that there is no conflict of interest between agents and principals, as opined by Dar et al. [31]. An implication that non-executive directors bring independence onto the board add to the diversity of skills and expertise of the directors. Moreover, non-executive directors alleviate agency problems and reduce managerial self-interests due to the separation of ownership and control. 
In this regard, our results are consistent with studies, such as Doğan [46], who advocate that firms should include more independent non-executive directors on their boards to ensure profitability and efficient operations. As such, we believe that by having more independent non-executive directors on corporate boards to oversee directors' actions will likely protect shareholders from directors who pursue self-interest over firm objectives.

Our results imply that by having more independent non-executive directors on corporate boards will ensure effective monitoring of executive directors' actions and this will likely motivate managers to perform in the interests of the shareholders, thereby improving ROE. However, the results are inconsistent with previous studies of Chen [27] and Syriopoulos and Tsatsaronis [50], which suggest that there is no relationship between board independence and firm performance. In his study, Chen [27] found that increasing the number of non-executive directors does not contribute to adding value to the company. Additionally, $\mathrm{Hsu}$ and $\mathrm{Wu}$ [4] conclude that independent directors do not contribute to corporate performance unless the board is gender-diversified.

To sum up, our results support the hypothesis that corporate governance influences firm financial performance. The following section below is the summary of this study.

\section{Conclusions}

This study examines the effect of the corporate governance structure on firm financial performance. Given the above evidence, one can say that board size and board independence are important factors that affect firm performance. The size of the board matters and the firm should monitor it to be effective. Board independence is also crucial for the functioning and profitability of the company which aligns with the King IV recommendation for firms to include more independent non-executive directors on the board for efficient monitoring and transparency. Results indicate that mining firms in South Africa are complying with the requirements of the King IV code of governance.

This study addresses some of the key recommendations of the King IV Code of Corporate Governance on board size and board independence regarding profitability. The descriptive statistics suggest that JSE SRI-listed mining firms are moving towards practising good corporate governance as shown by the majority of independent non-executive directors on the boards. The results also indicate that JSE-listed firms are incorporating a good number of independent non-executive directors on corporate boards, as shown by the statistical analysis. The result is consistent with King IV recommendations for firms to have a diverse corporate board consisting of more independent non-executive directors. There are indications that mining companies advocate and support sound governance through policies and strategies to achieve and maintain international corporate governance standards to implement sound ethical practices. A sign that mining firms in South Africa are working towards long-term growth and sustainability by adapting to changing demand trends, as recommended by the King IV Corporate Governance Code. Results from the random effects model suggest that there is a negative relationship between the board size and firm performance, as measured by ROE, implying that adding more directors to the board may decrease the financial results of the company, an indication that having a large board does not increase the value to the enterprise.

However, the results from the random-effects model suggest that there is a positive relationship between board independence and firm performance, as measured by ROE. An implication is that the more independent non-executive directors there are on the board, the more profitable the firm is likely to become. Per King IV, the board of directors should consist mostly of independent non-executive directors with the likelihood that its decisions will be in the best interests of the firm. Overall, our results indicate that by complying with the recommendations of the King IV Code on Corporate Governance to have more independent non-executive directors on their boards, mining firms tend to have a higher financial performance. As such, compliance with the corporate governance codes is crucial for corporate success. Compliance with sound corporate governance principles will not just benefit mining firms, but the economy as a whole. Such compliance is premised on the assertion that the South African mining sector is crucial for to its economic growth, development, and transformation. 
Not only will sound corporate governance compliance reduce mining firms' failures, but also improve foreign direct investment and employment.

Despite this, compliance with corporate governance principles does not necessarily translate into a significant economic benefit, and firms should, however, continue to comply with the King IV code for corporate governance for ethical reasons to meet stakeholder's social and environmental information needs. This study is one of the few studies on the relationship between corporate governance and firm financial performance in a developing country context, specifically in the South Africa mining industry, which is a key sector of its economy. However, the non-availability of data beyond 2010 may have limited the depth of this study. We suggest that complying with the recommendations of the King IV Code on good corporate governance by firms in South Africa should not be seen as a liability, but an ethical investment that may likely yield financial benefit in the long-term. Complying with good corporate governance should be included in strategy formulation by firms across industries as it has long-term results. Further studies are encouraged as more data become available on the JSE about firms' compliance with the King IV Code on Corporate Governance.

Acknowledgments: We wish to express our gratitude to the African Centre for Sustainability Accounting and Management (ACSAM), School of Accountancy, University of Limpopo for making funds available to cover the costs to publish our paper in open access.

Author Contributions: Isaih Dzingai is a graduate student under the supervision of Michael Bamidele Fakoya. This manuscript is the output from the dissertation that both authors have worked on.

Conflicts of Interest: The authors declare no conflict of interest. The founding sponsors had no role in the design of the study; in the collection, analyses, or interpretation of data; in the writing of the manuscript, and in the decision to publish the results.

\section{References}

1. Claessens, S. Corporate governance and development. World Bank Res. Obs. 2006, 21, 91-122. [CrossRef]

2. Krechovska, M.; Prochazkova, P.T. Sustainability and its Integration into Corporate Governance Focusing on Corporate Governance Management and Reporting. Procedia Eng. 2014, 69, 1144-1151. [CrossRef]

3. Allen, F. Corporate governance in emerging economies. Oxf. Rev. Econ. Policy 2005, 21, 164-177. [CrossRef]

4. Hsu, H. H; Wu, C.Y.H. Board composition, grey directors and corporate failure in the UK. Br. Acc. Rev. 2014, 46, 215-227. [CrossRef]

5. Crittenden, V.L.; Crittenden, W.F. Corporate governance in emerging economies: Understanding the game. Bus. Horiz. 2012, 55, 567-574. [CrossRef]

6. Marx, B; Watt, A.V.D; Bourne, P. Dynamic Auditing; Lexis Nexis: Durban, South Africa, 2011.

7. Jackson, R.D.C.; Stent, W.J. Auditing Notes for South African Students, 7th ed.; Lexis-Nexis: Durban, South Africa, 2010.

8. Ehikioya, B.I. Corporate governance structure and firm performance in developing economies: Evidence from Nigeria. Corp. Gov. Int. J. Bus. Soc. 2009, 9, 231-243. [CrossRef]

9. Bauer, R.; Guenster, N.; Otten, R. Empirical evidence on corporate governance in Europe: The effect on stock returns, firm value and performance. J. Asset Manag. 2004, 5, 91-104. [CrossRef]

10. Brown, L.D; Caylor, M.L. Corporate Governance and Firm Performance (7 December 2004). Available online: https: / poseidon01.ssrn.com/delivery.php?ID=59209812502600508212408210706512302503106203003602709 409609912607711011402312412502200211804403710500411701602500702711612402703806000103112210001 407500008809309304505200209509208107507010009202611611809701111201911110103106512001612001906 9104029\&EXT=pdf (accessed on 15 March 2017).

11. Jackling, B.; Johl, S. Board structure \& firm performance: Evidence from India's top firms. Corp. Gov. 2009, 17, 492-509.

12. Akbar, S.; Poletti-Hughes, J.; El-Faitouri, R.; Shah, S.Z.A. More on the relationship between corporate governance and firm performance in the UK: Evidence from the application of generalized method of moment's estimation. Res. Int. Bus. Financ. 2016, 38, 417-429. [CrossRef]

13. Ang, J.S.; Cole, R.A.; Lin, J.W. Agency costs and ownership structure. J. Financ. 2000, 55, 81-106. [CrossRef] 
14. Sarens, G.; Abdolmohammadi, M.J. Monitoring Effects of the Internal Audit Function: Agency Theory versus other Explanatory Variables. Int. J. Audit. 2011, 15, 1-20. [CrossRef]

15. Zalewska, A. Challenges of corporate governance: Twenty years after Cadbury, ten years after Sarbanes-Oxley. J. Empir. Sci. 2014, 27, 1-9. [CrossRef]

16. Connelly, B.L.; Ketchen, D.J.; Slater, S.F. Toward a "theoretical toolbox" for sustainability research in marketing. J. Acad. Mark. Sci. 2011, 39, 86-100. [CrossRef]

17. Adegbite, E. Corporate governance regulation in Nigeria. Corporate governance. Int. J. Bus. Soc. 2012, 12, 257-276.

18. Chhaochharia, V.; Grinstein, Y. Corporate governance and firm value: The impact of the 2002 governance rules. J. Financ. 2007, 62, 1789-1825.

19. Kyereboah-Coleman, A. Corporate governance and firm performance in Africa: A dynamic panel data analysis. Stud. Econ. Econom. 2008, 32, 1-24.

20. Vintila, G.; Gherghina, S.C. An Empirical Examination of the Relationship between Corporate Governance Ratings and Listed Firms' Performance. Int. J. Bus. Manag. 2012, 7, 1833-3850. [CrossRef]

21. Fuenzalida, D.; Mongrut, S.; Arteaga, J.R.; Erausquin, A. Good corporate governance: Does it pay in Peru. J. Bus. Res. 2013, 66, 1759-1770. [CrossRef]

22. Ngobo, P.V.; Fouda, M. Is 'Good' governance good for business? A cross-national analysis of firms in African countries. J. World Bus. 2012, 47, 435-449. [CrossRef]

23. Armeanu, D.S.; Vintila, G.; Gherghina, S.C.; Petrache, D.C. Approaches on Correlation between Board of Directors and Risk Management in Resilient Economies. Sustainability 2017, 9, 173-187. [CrossRef]

24. Ntim, C.G. An Integrated Corporate Governance Framework and Financial Performance in South African-Listed Corporations. S. Afr. J. Econ. 2013, 81, 373-392. [CrossRef]

25. Munisi, G.; Randoy, T. Corporate governance and firm performance across Sub-Saharan African countries. J. Bus. Econ. 2013, 70, 92-110. [CrossRef]

26. Azeez, A. Corporate governance and firm performance: Evidence from Sri Lanka. J. Financ. 2015, 3, 180-189. [CrossRef]

27. Chen, Y.R. Corporate governance and cash holdings: Listed new economy versus old economy firms. Corp. Gov. Int. Rev. 2008, 16, 430-442. [CrossRef]

28. Salvioni, D.M.; Gennari, F.; Bosetti, L. Sustainability and Convergence: The Future of Corporate Governance Systems? Sustainability 2016, 8, 1203-1227. [CrossRef]

29. Lam, T.Y.; Lee, S.K. Family ownership, board committees and firm performance: Evidence from Hong Kong. Corp. Gov. Int. J. Bus. Soc. 2012, 12, 353-366. [CrossRef]

30. Annuar, H.A.; Abdul Rashid, H.M. An investigation of the control role and effectiveness of independent non-executive directors in Malaysian public listed firms. Manag. Audit. J. 2015, 30, 582-609. [CrossRef]

31. Dar, L.; Naseem, M.A.; Niazi, G.S.K.; Rehman, R.U. Corporate governance and firm performance: A case study of Pakistan oil and gas firms listed in Karachi Stock exchange. Glob. J. Manag. Bus. Res. 2011, 11, 1-10.

32. Morey, M.; Gottesman, A.; Baker, B.; Godridge, B. Does better corporate governance result in higher valuations in emerging markets? Another examination using a new data set. J. Bank. Financ. 2009, 33, 254-262. [CrossRef]

33. Ammann, M.; Oesch, D.; Schmid, M.M. Corporate governance and firm value: International evidence. J. Empir. Financ. 2011, 15, 36-55. [CrossRef]

34. Li, C.; Zheng, W.; Chang, P.; Li, S. The correlation between corporate governance and market valuation: "Regime or signal?". China Financ. Rev. Int. 2015, 5, 19-33. [CrossRef]

35. Sharma, N. Extend of corporate governance disclosure by banks and finance firms listed on Nepal Stock Exchange. Adv. Acc. Inc. Adv. Int. Acc. 2014, 30, 425-439.

36. Letza, S.; Kirkbride, J.; Sun, X.; Smallman, C. Corporate governance theorising: Limits, critics and alternatives. Int. J. Law Manag. 2008, 50, 17-32. [CrossRef]

37. Wintoki, M.B.; Linck, J.S.; Netter, J.M. Endogeneity and the dynamics of internal corporate governance. J. Financ. Econ. 2012, 105, 581-606. [CrossRef]

38. Bebchuk, L.; Cohen, A.; Ferrell, A. What matters in corporate governance? Rev. Financ. Stud. 2009, 22, 783-827. [CrossRef]

39. Mangena, M.; Chamisa, E. Corporate governance and incidences of listings suspensions by the JSE of South Africa: An Empirical Analysis. Int. J. Acc. 2008, 43, 28-44. [CrossRef] 
40. INET BFA. Financial Indicators. September 2016. Available online: http://www.inetbfa.com/za (accessed on 15 March 2017).

41. Ntim, C.G.; Oseit, K.A. The impact of corporate board meetings on corporate performance in South Africa. Afr. Rev. Econ. Financ. 2011, 2, 83-103.

42. Mashayekhi, B.; Bazaz, M.S. Corporate governance and firm performance in Iran. J. Contemp. Acc. Econ. 2008, 4, 156-172. [CrossRef]

43. Khalif, H.; Souissi, M. The determinants of corporate disclosure: A meta-analysis. Int. J. Acc. Inform. Manag. 2010, 18, 198-219. [CrossRef]

44. Sheikh, N.; Wang, Z.; Khan, S. The impact of internal attributes of corporate governance on firm performance: Evidence from Pakistan. Int. J. Commer. Manag. 2013, 23, 38-55. [CrossRef]

45. Chen, T. Institutions, board structure, and corporate performance: Evidence from Chinese firms. J. Corp. Financ. 2015, 32, 217-237. [CrossRef]

46. Doğan, M. Does firm size affect the firm profitability? Evidence from Turkey. Res. J. Financ. Acc. 2013, 4, 53-59.

47. Orlitzky, M. Does firm size confound the relationship between corporate social performance and firm financial performance? J. Bus. Ethics 2001, 33, 167-180. [CrossRef]

48. Walls, J.L.; Berrone, P.; Phan, P.H. Corporate governance and environmental performance: Is there really a link? Strateg. Manag. J. 2012, 33, 885-913. [CrossRef]

49. Bliss, M.A. Does CEO duality constrain board independence? Some evidence from audit pricing. Acc. Financ. 2011, 51, 361-380. [CrossRef]

50. Syriopoulos, T.; Tsatsaronis, M. The corporate governance model of the shipping firms: Financial performance implications. Marit. Policy Manag. 2011, 38, 585-604. [CrossRef]

51. Hu, H.W.; Tam, O.K.; Tan, M.G.S. Internal governance mechanisms and firm performance in China. Asia Pac. J. Manag. 2010, 27, 727-749. [CrossRef]

52. Boubaker, S.; Derouiche, I.; Nguyen, D.K. Does the board of directors affect cash holdings? A study of French listed firms. J. Manag. Gov. 2015, 19, 341-370. [CrossRef]

53. Byrd, J.; Cooperman, E.S.; Wolfe, G.A. Director tenure and the compensation of bank CEOs. Manag. Financ. 2010, 36, 86-102. [CrossRef] 